DOI: $10.17805 /$ ggz.2018.4.2

\title{
О Вал. А. Лукове, тезаурусном подходе, других его концепциях и исследованиях
}

\author{
А. И. Ковалева \\ Московский гуманитарный университет \\ Т. Ф. Кузнецова
}

Московский педагогический государственный университет

В статье представлены биографические данные Валерия Андреевича Лукова на фоне его трактовки тезаурусного подхода и других концепций, выдвинутых им, и исследований, проведенных им и под его руководством. Публикаиия приурочена к 70-летию ученого.

Ключевые слова: тезаурусный подход; гуманитарные науки; Вл. А. Луков; Вал. А. Луков; сочиальное проектирование

\section{Valery A. Lukov, the Thesaurus Approach, His Other Conceptions and Studies

\author{
A. I. Kovaleva \\ Moscow University for the Humanities, \\ T. F. Kuznetsova \\ Moscow State Pedagogical University
}

The article presents biographical data on Valery Andreevich Lukov alongside his interpretations of the thesaurus approach and other conceptions that he has proposed as well as studies conducted by him and under his guidance. The publication commemorates the 70th anniversary of the scholar's birth.

Keywords: thesaurus approach; humanities; Vl. A. Lukov; Val. A. Lukov; social project management

Валерий Андреевич Луков - одна из заметных фигур в отечественной социологии, он входит в число лидеров научной школы Московского гуманитарного университета в области молодежных исследований. Его свойства концептуалиста отразились в названиях его работ: 88 раз в них употребляется слово «концепция». Но, конечно, дело не в употреблении тех или иных слов, а в свойствах личности, реализованных в них. Когда публикаций немного, трудно что-то определенное сказать об ученом. Когда их за полвека уже больше 1300 - есть все основания для анализа, основанного на статистике. 
14,15 \% публикаций Вал. А. Лукова по своим названиям связаны с выдвинутым им и братом-близнецом Владимиром Андреевичем Луковым (19482014), ставшим в начале XXI века одним из выдающихся отечественных литературоведов и культурологов, тезаурусным подходом.

Тезаурус, согласно тезаурусному подходу, представляет собой конструкиию знаний, которая есть у каждого субъекта действия (человека, группы людей, социальных общностей и т. д.). У нее есть два назначения, иначе говоря, она эффективно применяется в двух ситуациях. Первая связана с ориентацией в окружающей среде. Эта задача стоит, можно сказать, ежеминутно, и хотя она чаще всего не замечается, субъекту действия приходится ее решать все время для поддержания равновесия со своим окружением. Вторая направлена на саморазвитие, создание нового. Это не только стремление, обнаруживаемое в творческих специальностях: актер, композитор, живописец и др. У столяра, например, не меньше творческих задач (чем заместить отсутствующий материал, как в ограниченном числе инструментов найти недостающий и т. д.). И в том и в другом случае нашему субъекту нужны не все знания, а те, которые дают возможность для решения ориентационных и сверхориентационных задач. Для обеспечения ее всеобщности не подойдет научная классификация. Зато уместной станет конструкция знаний по модели от своего к чужому, которая блокирует чуждое. По видимости такая модель проста, а ее базовая ось дифференциации «свое - чужое - чуждое» примитивизирует человеческое мышление. Но повседневность и построена на минимизации специальных знаний, на первоэлементах крайне простых, зато всеобщих, которые потом через системы дериваций (отклонений) и усложнений приобретают характеристики специального знания, нередко непонятного несведущим и выступающего своего рода защитным механизмом, оберегающим носителей сакрального и специализированного знания от невежд.

Особенности тезаурусного подхода, изложенные Вал. А. Луковым и Вл. А. Луковым наиболее полно в фундаментальной монографии «Тезаурусы» (Луков В., Луков Вл., 2008), неоднократно раскрывались в рецензиях на эту книгу (Гуревич, 2008; Костина, 2008; Болотин, 2009; Ищенко, 2009). Методологические аспекты подхода обстоятельно представлены в продолжении «Тезаурусов» — «Тезаурусах ІІ» (Луков В., Луков Вл., 2013), последующих книгах и статьях. Многое проясняют и биографические данные. К ним мы и обратимся.

Начало научным публикациям Вал. А. Лукова было положено тезисами доклада «Некоторые особенности языка посланий Ивана Грозного», представленного студентами-первокурсниками Московского государственного 
педагогического института имени В. И. Ленина братьями-близнецами Валерием и Владимиром Луковыми на IX научно-теоретической и методической конференции, организованной кафедрой русской литературы в мае 1966 г. (а братьям тогда исполнилось по 17 лет) (Луков В., Луков Вл., 1966). Надо отметить, что из первых публикаций никак еще не следовало, что Валерий Андреевич Луков отметит свое 70-летие четырехтомной «Тезаурусной социологией», знаменующей его вклад в современную науку (Луков, 2018abcd). Многое надо отнести к личным качествам братьев, к десятикратному увеличению их сил, когда они работали вместе (это прежде всего касается разработки тезаурусного подхода). Что-то надо отнести к умению обоих братьев читать огромное число книг и статей (на множестве языков), выявляя главное, относящееся к теме исследования. Обоим присуще уже отмеченное выше концептуальное мышление, что позволяет находить оригинальные решения. Обоим присуща междисциплинарность, а ее следствием неизбежно становится широта научного поиска, многообразие тем, исследуемых сюжетов. Важна и работа в разных жанрах. И все же публикация первых докладов, еще студенческих, но уже собственно научных, в трудах, ученых записках вузов, научных журналах - рядом с известными учеными, с одной стороны, показательна, с другой — и есть путь в науку. Таков всегда и путь в общественно значимую практику, без которой любые статьи и книги становятся «плетением словес» (хотя и не в смысле особого стиля, который впервые так назвал книжник XIV - начала XV века Епифаний Премудрый).

Учитывая это, мы без дополнительных слов, излагая только факты, обрисовываем биографию Вал. А. Лукова.

Валерий Андреевич Луков - доктор философских наук, профессор, заслуженный деятель науки РФ (2006), директор Центра социального проектирования и тезаурусных концепций Института фундаментальных и прикладных исследований Московского гуманитарного университета.

В той части гражданского общества, которая связана с наукой, Вал. А. Луков - активный участник. В 2002 г. он был назначен заместителем ректора Московской гуманитарно-социальной академии по научной работе, в 2008 г. - проректором по научной и издательской работе этого вуза, который в соответствии с достигнутым статусом именовался уже Московским гуманитарным университетом. В этой должности он работал до 2015 г.

Вал. А. Луков - заместитель председателя диссертационного совета Д 521.004.07 при МосГУ по социологии культуры и культурологии; член Научного совета РАН «Новые явления в общественном сознании и социальной практике»; заместитель главного редактора журнала «Знание. Понима- 
ние. Умение», главный редактор журнала «Горизонты гуманитарного знания», член редколлегий журнала «Социологические исследования» и ряда других научных журналов, академик Международной академии наук (IAS, Инсбрук, Австрия), академик-секретарь Отделения гуманитарных наук Русской секции этой академии; академик Международной академии наук педагогического образования; член ИК-34 «Социология молодежи» Международной социологической ассоциации. Эксперт Российского фонда фундаментальных исследований. В 2015 г. был утвержден Президиумом Российской академии наук экспертом РАН. С 2014 г. он также член жюри Бунинской премии единственной премии в области современной русской литературы и русского языка, учрежденной негосударственными вузами.

Основное его научно-организационное достижение - руководство почти на протяжении 15 лет (с 2004 по 2017 г.) Институтом фундаментальных и прикладных исследований Московского гуманитарного университета, где удалось собрать выдающихся ученых и научную молодежь и небольшим коллективом решать многие актуальные задачи науки. В 2012 г. по результатам Всероссийского конкурса «100 лучших вузов России» в номинации «Лучший НИИ, НИЦ при вузе» этот Институт был признан лауреатом.

Основное направление научных исследований Вал. А. Лукова - социология молодежи; социально-правовые проблемы государственной молодежной политики; социальное и социокультурное проектирование; теория и методология тезаурусного подхода, который он успешно применил к теориям молодежи. Он выдвинул тезаурусные концепции молодежи, социализации, теории воспитания и др. Участие Лукова в создании федеральных и региональных актов законодательства определило соединение в его исследованиях молодежи социологических, правовых, психологических и др. аспектов, утверждение междисциплинарности. Его статьи по социологии молодежи признавались лучшими в главном социологическом журнале страны «Социологические исследования». Его монография «Теории молодежи» (Луков, 2012) была признана «книгой года» по результатам Всероссийского конкурса «100 лучших вузов России». Это, среди прочего, отражало, что опирающаяся на изучение более 1000 книг, статей, исследований по проблемам молодежи монография - наиболее полное из когда-либо предпринимавшихся изложений и обобщений теорий молодежи, получивших признание в мире со времени появления первых из них и до наших дней.

В последние годы он выдвинул концепцию биосоциологии молодежи, которая непосредственно связывается с информационным обществом (Луков, 2013; Луков, Погорский, 2014). В ряде работ он показал неоднозначность от- 
ношения молодежи к перспективам «улучшения» человека, распространяемым, среди прочего, в версии трансгуманизма (иммортализм, киборгизация, бесполость и т. д.) (Луков, 2017, 2018еf).

Но это нынешние времена. А родился Вал. А. Луков в Москве в 1948 г. в семье отца-столяра и матери-бухгалтера. Будучи школьником, вместе с братом-близнецом Владимиром создавал в режиме социальных проектов школьные драматические студии и театры. Он стал лауреатом первого Фестиваля искусств пионеров и школьников г. Москвы (1964), он - первый школьник, ставший председателем созданных в 1964 г. Пионерских музыкальных собраний (Колонный зал Дома союзов, руководитель от Союза композиторов СССР — композитор Д. Б. Кабалевский, ведущие собраний первого года дирижер К. П. Кондрашин, виолончелист М. Л. Ростропович, композитор Д. Д. Шостакович и др.).

В 1965-1969 гг. учился на факультете русского языка и литературы Московского государственного педагогического института имени В. И. Ленина. Преподавал по комсомольской путевке русскую литературу на рабфаке (форма довузовской подготовки работающей молодежи). По его и брата инициативе (а они учились вместе, имели именные стипендии: Валерий — имени А. С. Пушкина, Владимир - имени В. Г. Белинского) было создано КОНСО - курсовое отделение научного студенческого общества, куда вошли десятки студентов-филологов. Именно к 1960-м гг. относятся его первые научные публикации. После окончания с отличием пединститута Вал. А. Луков поехал с братом по распределению в Кемеровскую область и работал организатором внеклассной и внешкольной работы средней школы № 35 г. Осинники. В период организационной и преподавательской работы в школе и потом, когда он перешел на комсомольскую работу (заведующий отделом учащейся молодежи и пионеров Осинниковского горкома ВЛКСМ), Валерий продолжал задумывать и осуществлять социальные и социокультурные проекты (создание ударного взвода коммунаров, побеждавшего в школьных соревнованиях делегации всех городов этой урбанизированной сибирской области; школьные театры и т. д.).

В 1970-1972 гг. Вал. А. Луков - слушатель ВКШ при ЦК ВЛКСМ, которую так же, как и педвуз, окончил с отличием, а затем секретарь комитета ВЛКСМ этого вуза, где социальное проектирование было развито в разных формах (студенческие стройотряды, педотряды, интерклуб с представителями более 50 стран, литературные встречи с космонавтами, спортсменами, видными писателями, среди которых К. М. Симонов, Ч. Т. Айтматов, поэтамишестидесятниками — А. А. Вознесенским, Б. Ш. Окуджавой, Е. А. Евтушен- 
ко и др., творческие отчеты московских театров, включая приезд Ю. П. Любимова и актеров Театра на Таганке В. С. Высоцкого, А. С. Демидовой и др., фестивали искусств союзных республик - Белоруссии, Казахстана и т. д.).

С 1973 г. начал работать в научной сфере: первая работа - младший научный сотрудник научно-исследовательского сектора международного молодежного движения ВКШ при ЦК ВЛКСМ. В 1976-1989 гг. работал в Научно-исследовательском центре ВКШ при ЦК ВЛКСМ, заведовал отделами международного молодежного движения, комсомольского строительства и др. Сыграл видную роль в становлении теории и практики международного молодежного движения как научной и учебной дисциплины. В 1976 г. вместе с братом создал в ВКШ агиттеатр, привлекая более 30 слушателей первого курса факультета истории и коммунистического воспитания.

В 1980-е гг. Вал. А. Луков - член советских делегаций на фестивалях дружбы молодежи СССР и ГДР, Болгарии, Польши, Чехословакии, в 1985 г. - руководитель научных программ Клуба советской делегации на XII Всемирном фестивале молодежи и студентов (Москва). В 1987-1991 гг. — наряду с руководством отделом Научно-исследовательского центра ВКШ работал в форме законотворческого проектирования во Временном молодежном творческом коллективе «Закон о молодежи», созданном по инициативе И. М. Ильинского и по решению ЦК ВЛКСМ на базе НИЦ. ВМТК - часть крупного замысла по преобразованию молодежной политики в стране: НИЦ ВКШ, пользуясь конституционным правом законодательной инициативы ВЛКСМ, начал подготовку Закона о молодежи, который после нескольких лет работы и всенародного обсуждения проектов приобрел форму Закона СССР «Об общих началах государственной молодежной политики в СССР», принятого в апреле 1991 г. Принятие этого закона по проекту, разработанному в НИЦ, означало и принятие определявшей его основы концепции государственной молодежной политики. Наиболее активные участники этой работы, и Вал. А. Луков в их числе, были удостоены премии Ленинского комсомола (1991).

В 1992 г., работая заместителем главного редактора государственного издательства «Педагогика-Пресс», Вал. А. Луков инициировал и вел международный социальный и издательский проект «Всемирная детская энциклопедия “Глобус"», поддержанный Президентом РФ Б. Н. Ельциным, крупнейшими учеными России академиками РАН Д. С. Лихачевым, Е. П. Челышевым, Ю. С. Степановым, президентом Национальной академии наук Украины Б. Е. Патоном, поэтом Р. Г. Гамзатовым, телеведущим Н. Н. Дроздовым, кинорежиссером Р. А. Быковым, шведской писательницей Астрид Линдгрен, 
норвежским путешественником Туром Хейердалом, американским лингвистом Ноамом Хомским и другими видными представителями мировой науки и педагогической деятельности из десятков стран мира. В проекте впервые Вал. А. и Вл. А. Луковыми был разработан и практически применен тезаурусный подход. Филологические увлечения юности братьев Луковых сыграли заметную роль в обосновании получившего теперь известность в России и за рубежом этого общеметодологического подхода, основанного на теории социальной субъектности, разработанной и примененной Вл. А. Луковым в литературоведении (особенно в многочисленных работах о шекспиризации, шекспиризме, культе Шекспира, шекспиросфере) и культурологии (теория субъектной культурологии), а Вал. А. Луковым в социальной философии и социологии. Идеи тезаурусного подхода нашли отражение в фундаментальной монографии 2008 г. Вал. А. и Вл. А. Луковых «Тезаурусы: Субъектная организация гуманитарного знания» (Луков В., Луков Вл., 2008) - наиболее полном и систематичном к тому времени изложении тезаурусной концепции как теоретико-методологический основы, продуктивной для развития междисциплинарных исследований в области гуманитарных и социальных наук. Продолжение этой линии составили их монография «Тезаурусы II: Тезаурусный подход к пониманию человека и его мира» (Луков В., Луков Вл., 2013), вышедшая в 2013 г., книги и многочисленные статьи. За несколько лет до этого, в 2005 г. в издательстве «Наука» вышла книга Вал. А. Лукова и Д. Л. Аграната «Курсанты: Плац. Быт. Секс» (Луков, Агранат, 2005), в которой на основе социологического и социально-психологического исследования, проведенного в милицейских вузах, была выявлена значимость тезаурусного подхода для эмпирических исследований. Вступительную статью к этой книге (под названием «Курсанты в зеркале интересной социологии») написал выдающийся философ и биоэтик член-корреспондент РАН Б. Г. Юдин (Юдин, 2005).

В 1994-2002 гг. Вал. А. Луков - профессор кафедры социологии и социальной работы Института молодежи, затем заместитель заведующего этой кафедрой по научной работе. Одновременно вел федеральные и региональные законотворческие проекты: Федеральный закон «О государственной поддержке молодежных и детских общественных объединений» (принят в 1995 г.), Федеральный закон «Об основных гарантиях прав ребенка в Российской Федерации» (принят в 1998 г.) и др. В 1995-2000 гг. - заместитель председателя Экспертно-консультативного совета при Комитете по делам женщин, семьи и молодежи Государственной Думы РФ, в 2004-2005 гг. — вновь член этого совета. Председатель Экспертно-консультативного совета Комитета 
Российской Федерации по делам молодежи по проектам и программам молодежных и детских объединений. Ответственный редактор и соавтор государственных докладов о положении молодежи России $(1995,1998,2000)$. Все это определяло актуальность его работ в области социологии молодежи, но также и направленность его научных исследований на социальное и социокультурное проектирование, социальную экспертизу и т. д. В этих направлениях он и получил наибольшее признание. Его участие в создании федеральных и региональных актов законодательства, работа по применению науки в органах и организациях, ответственных за проведение государственной молодежной политики, определили соединение в его исследованиях молодежи социологических, правовых, психологических и других аспектов, утверждение междисциплинарности.

Публикации Вал. А. Лукова отражают его научно-исследовательские работы, выполненные в разных областях: социальной философии, социологии, культурологии, социальной психологии, истории психологии, политологии, антропологии, филологии и др. Наиболее крупные работы последних лет - монографии и учебные пособия «Социальное проектирование» (9-е изд. 2010), «К теории социальных общностей» (2009), «Теории молодежи: междисциплинарное исследование» (2012), «Биосоциология молодежи: теоретико-методологические основания» (2013), «Тезаурусная социология» в 4 т. (2018) и др., а также книги, написанные в соавторстве с учениками и последователями, в составе авторских коллективов: «Новые идеи в социологии управления» (с М. Г. Солнышкиной, 2011), «Социальная экспертиза» (с Д. А. Тихомировым, 2012), «Добрачные сексуальные отношения молодежи: дилемма социальной нормы и отклонения» (с Д. А. Тихомировым, 2012), «Государственная молодежная политика: российская и мировая практика реализации в обществе инновационного потенциала новых поколений» (в составе авторского коллектива, 2013), «Новые идеи в социологии» (в составе авторского коллектива, 2013), «Информационное общество и молодежь» (с Э. К. Погорским, 2014), «Трансдисциплинарность в философской науке: Подходы. Проблемы. Перспективы» (в составе авторского коллектива, 2015), «Социология молодежи: научная школа Московского гуманитарного университета» в 2 ч. (в составе авторского коллектива, 2016, 2018) и др. В 2007 г. в России и Польше вышла книга Вал. А. Лукова «Глобализация и воспитание» с изложением концепции социологии воспитания, которая отразила его педагогическую работу и исследования в польских вузах Щецина и Ольштына и развита в его статьях последнего времени (Łukov, 2007; Луков, 2007). 
Как исследователь молодежных проблем развивает социальнофилософскую концепцию молодежи и молодежной политики, выдвинутую И. М. Ильинским, а также его ключевые идеи «образовательной революции» и системной связи «знания - понимания - умения» («триада Ильинского»). Организатор крупных социологических исследований, в том числе годовых этапов всероссийского мониторинга «Российский вуз глазами студентов» (2004-2009 гг.), проведенного в 15 регионах России эмпирического опроса молодежи «Комсомол-100» (Луков В., Луков С., 2018) и др.

Для развития отечественной науки переводы классики очень важны, они нередко еще до 1990-х гг. были недоступны в таких областях, как психология, социология, педагогика. В этом аспекте особо существенно то, что под редакцией Вал. А. Лукова изданы переводы классических работ А. Бине, Э. Дюркгейма, Э. Кречмера, Ж. Пиаже, З. Фрейда и его школы, В. Штерна, а также многотомные сборники законодательства о молодежи.

Вокруг Вал. А. Лукова сложилась научная школа исследований по молодежной проблематике и социальному проектированию, основанная на тезаурусной методологии. Под его руководством, в частности, защищены 43 кандидатских и 5 докторских диссертаций, подготовлено более 100 монографий и сборников научных трудов. Он известен международному научному сообществу своими выступлениями на международных и всероссийских конференциях (в том числе с 2004 г. один из организаторов ежегодных международных научных конференций «Высшее образование для XXI века» в МосГУ) и публикациями (работы Вал. А. Лукова опубликованы в Австрии, Германии, Польше, США, Украине, Финляндии, Чехии и других странах).

В 2002-2017 гг. он осуществлял 96 проектов, поддержанных научными фондами, в том числе как руководитель: проект РГНФ «Государственная молодежная политика: российская и мировая практика реализации в обществе инновационного потенциала новых поколений», 2011-2013 гг.; проект РФФИ «Теории молодежи: Междисциплинарное исследование», 2007-2009 гг.; проект РФФИ «Биосоциология молодежи: теоретико-методологические основания», 2011-2013 гг.; проект РФФИ «Социология молодежи: Электронная энциклопедия», 2015-2016 гг. и др.

В 2018 г. Вал. А. Луков по конкурсу возглавил Центр социального проектирования и тезаурусных концепций Института фундаментальных и прикладных исследований Московского гуманитарного университета. Этот год ознаменовался и тем, что под общей редакцией Вал. А. Лукова вышли собранные им энциклопедические очерки Вл. А. Лукова «Европейская культура в русском тезаурусе» в 3-х томах, вторая часть книги «Социология молодежи: 
Научная школа Московского гуманитарного университета», многие статьи в ведущих российских научных журналах, а главное - четырехтомная монография Вал. А. Лукова «Тезаурусная социология», составляющая его значительный вклад в социологическую науку и в целом в науку XXI века (Луков, 2018abcd).

\section{СПИСОК ЛИТЕРАТУРЫ}

Болотин, И. С. (2009) Тезаурусы как инструмент преподавателя // Высшее образование в России. № 5. С. 169-172.

Гуревич, П. С. (2008) [Рец. на кн.:] Луков Вал. А., Луков Вл. А. Тезаурусы: Субъектная организация гуманитарного знания. М., 2008. 784 с. // Эдип. № 3 (6). С. 165-166.

Ищенко, Ю. А. (2009) Размышления над книгой // Знание. Понимание. Умение. № 3. С. 262-268.

Костина, А. В. (2008) Тезаурусный подход как новая парадигма гуманитарного знания // Обсерватория культуры. № 5. С. 102-109.

Луков, В. А. (2007) Воспитание и глобализация: Проблемы социологии воспитания : науч. монография. М. : Флинта ; Наука. 144 с.

Луков, В. А. (2012) Теории молодежи: Междисциплинарный анализ : науч. монография М. : «Канон+» РООИ «Реабилитация». 528 с.

Луков, В. А. (2013) Биосоциология молодежи: теоретико-методологические основания : науч. монография. М. : Изд-во Моск. гуманит. ун-та. 430 с.

Луков, В. А. (2017) Проекты «улучшения» человека: что об их необходимости и последствиях думает российская молодежь? // Знание. Понимание. Умение. № 4. С. 117-133. DOI: 10.17805/zpu.2017.4.11

Луков, В. А. (2018а) Тезаурусная социология : в 4 т. : монография. М. : Изд-во Моск. гуманит. ун-та. Т. 1.608 с.

Луков, В. А. (2018b) Тезаурусная социология : в 4 т. : монография. М. : Изд-во Моск. гуманит. ун-та. Т. 2. 576 с.

Луков, В. А. (2018c) Тезаурусная социология : в 4 т. : монография. М. : Изд-во Моск. гуманит. ун-та. Т. 3.508 с.

Луков, В. А. (2018d) Тезаурусная социология : в 4 т. : монография. М. : Изд-во Моск. гуманит. ун-та. Т. 4.640 с.

Луков, В. А. (2018е) Российская молодежь о биотехнологических проектах «улучшения» человека // Социологические исследования. № 4. С. 7381.

Луков, В. А. (2018f) Биосоциология молодежи как новая научная дисциплина [Электронный ресурс] // Горизонты гуманитарного знания. № 2 . C. 3-16. URL: http://journals.mosgu.ru/ggz/article/view/752 (дата обращения: 10.08.2018). DOI: $10.17805 /$ ggz.2018.2.1 
Луков, В. А., Агранат, Д. Л. (2005) Курсанты: Плац. Быт. Секс : Социологическое и социально-психологическое исследование. М. : Флинта ; Наука. $272 \mathrm{c.}$

Луков, В. А., Луков, Вл. А. (1966) Некоторые особенности языка посланий Ивана Грозного // Язык и стиль художественного произведения : тезисы докл. IX науч.-теорет. и метод. конференции, организуемой кафедрой рус. лит-ры, 26-28 мая 1966 г. / Московск. гос. пед. ин-т им. В. И. Ленина ; под общ. ред. проф. А. И. Ревякина. М. 168 с. С. 22-23.

Луков, В. А., Луков, Вл. А. (2008) Тезаурусы: Субъектная организация гуманитарного знания : науч. монография. М. : Изд-во Нац. ин-та бизнеса. $784 \mathrm{c.}$

Луков, В. А., Луков, Вл. А. (2013) Тезаурусы II: Тезаурусный подход к пониманию человека и его мира : науч. монография. М. : Изд-во Нац. ин-та бизнеса. $640 \mathrm{c.}$

Луков, В. А., Луков, С. В. (2018) Комсомол-100: социологическое исследование об исторической памяти российской молодежи [Электронный ресурс] // Научные труды Московского гуманитарного университета. № 6. (В печати).

Луков, В. А., Погорский, Э. К. (2014) Информационное общество и молодежь : науч. монография. М. : Изд-во Моск. гуманит. ун-та. 160 с.

Юдин, Б. Г. (2005) Курсанты в зеркале интересной социологии // Луков, В. А., Агранат, Д. Л. Курсанты: Плац. Быт. Секс : Социологическое и социально-психологическое исследование. М. : Флинта ; Наука. 272 с. С. 3-7.

Łukov, Wal. (2007) Problemy wychowania w społeczeństwie globalmym. Olsztyn : Wyższa szkoła inf. i ekon. 87 s.

Дата поступления: 12.08.2018 г.

Ковалева Антонина Ивановна - доктор социологических наук, профессор, проректор по учебной работе Московского гуманитарного университета. Адрес: 111395, Россия, г. Москва, ул. Юности, д. 5. Тел.: +7 (499) 37451-10. Эл. адрес: akovaleva@mosgu.ru

Kovaleva Antonina Ivanovna, Doctor of Sociology, Professor, Vice-Rector for Academic Work, Moscow University for the Humanities. Postal address: 5, Yunosti St., 111395 Moscow, Russian Federation. Tel.: +7 (499) 374-51-10. Email: akovaleva@mosgu.ru

Кузнецова Татьяна Федоровна - доктор философских наук, профессор; профессор кафедры культурологии Московского педагогического государственного университета, академик Международной академии наук (Инсбрук, Австрия). Адрес: 119571, г. Москва, пр-т Вернадского, д. 88. Тел.: +7 (495) 539-55-19. Эл. адрес: kult@mpgu.edu 
Kuznetsova Tatiana Fedorovna, Doctor of Philosophy, Professor, Department of Culturology, Moscow State Pedagogical University; Full member, International Academy of Science (IAS, Innsbruck, Austria). Postal address: 88 Prospekt Vernadskogo, 119571 Moscow, Russian Federation. Tel.: +7 (495) 539-55-19. Email: kult@mpgu.edu

Для циитирования:

Ковалева А. И., Кузнеиова Т. Ф. О Вал. А. Лукове, тезаурусном подходе, других его концепциях и исследованиях [Электронный ресурс] // Горизонты гуманитарного знания. 2018. № 4. C. 15-26. URL: http://journals.mosgu.ru/ggz/ article/view/844 (дата обращения: дд.мм.гггг). DOI: 10.17805/ggz.2018.4.2 